\title{
Pengaruh Pembelajaran Berbasis Masalah dan Penemuan Terbimbing Terhadap Keterampilan Proses Sains Siswa SMA Negeri 1 Langsa
}

\author{
Cut Badzlina Roza ${ }^{*}$, Hasruddin $^{2}$, Syahmi Edi $^{2}$ \\ ${ }^{1}$ Alumni Program Studi Pendidikan Biologi Program Pascasarjana Universitas Negeri Medan, Sumatera Utara, \\ Indonesia \\ ${ }^{2}$ Program Studi Pendidikan Biologi, Program Pascasarjana, Universitas Negeri Medan \\ *Email: cudbadzlina@gmail.com
}

\begin{abstract}
This research aimed to determine the effect of learning model on: science process skills in SMA Negeri 1 Langsa. The research applied experimental queasy method research with 3 classes which were using by cluster randome technique. Class A learnt with problem based learning model, class B with guided discovery lerning model, while class $\mathrm{C}$ (control) learnt with conventional lerning model. the data analysis technique used Covariat Analysis (ANACOVA) at the level of significance $\alpha$ $=0,05$ by using SPSS 21.0. The result showed: there was significant effect of learning models on student's science process skill $(\mathrm{F}=50.953 ; \mathrm{P}=0.00)$. student's science process skill learnt by problem based learning $(84.5 \pm 5.3)$ significantly higher than guided discovery $(75.30 \pm 7.7)$, and conventional learning models $(65.90 \pm 8.1)$.
\end{abstract}

Key words: Problem Based Learning, Guided Discovery, Science Process Skill

\section{PENDAHULUAN}

Berdasarkan PISA 2009, capaian sains untuk Indonesia berada pada peringkat ke60 dari 65 negara dengan skor 383, hasil penelitian tersebut menunjukkan masih relatif rendah bila dibandingkan dengan negara-negara lainnya. Pencapaian tersebut masih banyak berada pada level kemampuan dasar dan belum sampai pada level kemampuan yang lebih tinggi. Pada tahun 2013, hasil PISA untuk siswa Indonesia sangat memprihatinkan yaitu Indonesia menempati urutan dua terbawah yaitu dengan peringkat ke-63 dari 65 negara.

Strategi pembelajaran yang selama ini diterapkan tidak mengaktifkan siswa dalam kegiatan pembelajaran secara maksimal. Minat belajar siswa kurang, siswa tidak terbiasa belajar dengan diawali permasalahan-permasalahan, sehingga diduga belum banyak siswa yang memiliki keterampilan proses sains. Siswa kurang kesempatan untuk mengembangkan kemampuan serta keterampilannya. Hal ini menyebabkan siswa menjadi kurang terlatih untuk mengembangkan daya nalarnya dalam memecahkan permasalahan dan mengaplikasikan materi yang telah dipelajari dalam kehidupan nyata. Siswa juga kurang diberi kesempakatan dalam mengaplikasikan keterampilan yang dimiliki dalam suatu kegiatan ilmiah yang akhirnya membuat siswa dapat menemukan pengetahuan baru. Situasi belajar seperti ini juga menjadikan pembelajaran menjadi kurang menarik karena siswa cenderung pasif, kurang responsif, kurang kreatif dan kritis.

Pembelajaran berbasis masalah merupakan pembelajaran yang lebih menekankan pada aktifitas siswa dan menjadikan siswa lebih banyak berinteraksi dengan objek dan peristiwa sehingga siswa memperoleh pemahaman (kontruktivisme). Peran guru hanya sebagai fasilitator, bukan pentransfer pengetahuan (Herman, 2007). Model pembelajaran berbasis masalah ini juga diharapkan mampu menarik perhatian siswa melalui keterlibatan aktif siswa dan mampu meningkatkan aktivitas dan keterampilan proses sains siswa.

Keterampilan proses sains sangat penting untuk pengembangan pemahaman siswa dalam menerapkan konsep ilmiah dan meningkatkan proporsi belajarnya. Sehingga melalui pengalaman-pengalaman dalam pembelajaran keterampilan proses, siswa dapat mencapai keahlian dalam pembelajaran yang bermakna dalam prosedur pemecahan masalah secara ilmiah dan menerapkan pemahaman ilmiah 
tersebut dalam kehidupan sehari-hari (Ango, 2002). Oleh karena itu, pendekatan pembelajaran pada keterampilan proses siswa sangat penting dalam meningkatkan hasil belajar siswa.

Dalam hal mengaplikasikan keterampilan yang dimiliki siswa dalam suatu kegiatan ilmiah yang akhirnya membuat siswa dapat menemukan pengetahuan baru, perlu diterapkan model pembelajaran penemuan terbimbing. Model pembelajaran penemuan terbimbing juga diharapkan mampu menarik perhatian peserta didik melalaui keterlibatan aktif siswa serta mampu meningkatkan keterampilan proses sains peserta didik.dalam penemuan terbimbing guru berfungsi sebagai fasilitator. Guru bertindak

Penelitian dilaksanakan di SMA Negeri 1 Langsa. Populasi penelitian adalah siswa kelas XI. Dalam penelitian ini tiga kelas yang diambil sebagai sampel penelitian, yaitu kelas A dan kelas B sebagai kelas eksperimen dan kelas C sebagai kelas kontrol. Variabel bebas dalam penelitian ini adalah model pembelajaran berbasis masalah dan model penemuan terbimbing sedangkan variabel terikatnya adalah keterampilan proses sains siswa. Desain penelitian yang digunakan dalam penelitian kuasi eksperimen ini adalah desain pre-pos tes. Instrument yang digunakan dalam penelitian ini yaitu soal tes keterampilan proses sains siswa. Dalam penyusunan instrumen tes digunakan beberapa analisis instrumen tes, yaitu validitas, reliabilitas, tingkat kesukaran dan daya pembeda. Sebelum pembelajaran, ketiga kelas diberikan pretes kemudian diberikan

Berdasarkan pretes keterampilan proses sains siswa menunjukkan bahwa kemampuan awal siswa pada kelas Pembelajaran Berbasis Masalah diperoleh nilai tertinggi 40 dan nilai terendah 13 dengan rata-rata dan standar deviasi 28,93 \pm 6,94 dan hasil uji normalitas dengan menggunakan uji Kolmogorov-Smirnov disimpulkan bahwa kemampuan awal siswa kelas pembelajaran berbasis masalah $(\mathrm{Z}=$ 0,128; $\mathrm{P}=0,200)$. Pada kelas penemuan sebagai penunjuk jalan dan memabantu peserta didik agar dapat menggunakan ide, konsep, dan keterampilan yang sudah mereka pelajari sebelumnya untuk menemukan pengetahuan baru. Pelaksanaan pembelajaran dengan model penemuan terbimbing ini apabil dilakukan dengan efektif, cenderung akan menghasilkan ingatan dan transfer jangka panjang yang lebih baik.

Berdasarkan latar belakang diatas, tujuan penelitian ini adalah untuk mengetahui: pengaruh pembelajaran yang menggunakan model pembelajaran berbasis masalah, penemuan terbimbing dan konvensional terhadap keterampilan proses sains siswa pada materi sistem pencernaan di kelas XI SMA Negeri 1 Langsa.

\section{METODE PENELITIAN}

perlakuan yang berbeda. Pada kelas eksperimen diterapkan model pembelajaran berbasis masalah dan model penemuan terbimbing sedangkan kelas kontrol diterapkan pembelajaran konvensional. Setelah itu, kedua kelas diberikan postes. Uji hipotesis dilakukan jika distribusi normal dan homogen. Untuk itu dilakukan uji normalitas dan homogenitas. Untuk uji hipotesis dilakukan dengan menggunakan uji anacova. Apabila hasil uji statistik menunjukkan pengaruh yang signifikan, maka analisis dilanjutkan dengan uji Tukey's. Data kemudian dianalisis dengan menggunakan software SPSS 21.0. Kriteria pengujian yaitu jika angka signifikansi yang dihasilkan lebih kecil daripada $\alpha=0,05$ berarti $\mathrm{H}_{\mathrm{a}}$ diterima. Artinya terdapat efek dan interaksi antara variabel bebas terhadap variabel terikat.

\section{HASIL DAN PEMBAHASAN}

terbimbing, kemampuan awal diperoleh nilai tertinggi 43 dan nilai terendah 12 dengan nilai rata-rata dn standar deviasi 29,17 $\pm 6,91$ serta memiliki sebaran data berdistribusi normal $(Z=0,111 ; P=0,200)$. Sementara pada kelas konvensional dari hasil pretes diperoleh nilai tertinggi 39dan nilai terendah 16 dengan rata-rata nilai dan standar deviasi 26,77 \pm 6,19 serta memiliki sebaran data berdistribusi normal $(\mathrm{Z}=0,158 ; \mathrm{P}=0,055)$. 
Selanjutnya dari hasil postes keterampilan proses sains siswa yang dibelajarkan dengan model pembelajarn berbasis masalah diperoleh nilai tertinggi 94 dan nilai terendah 76 dengannilai ratarata dan standar deviasi $84,5 \pm 5,32$ serta berdistribusi normal $(\mathrm{Z}=0,116 ; \mathrm{P}=0,200)$. Pada kelas penemuan terbimbing dari hasil postes diperoleh nilai tertinggi 90 dan nilai terendah 57 dengan rata-rata nilai dan standar deviasi 75,30 \pm 7,66 serta sebaran data berdistribusi normal $(\mathrm{Z}=0,103 ; \mathrm{P}=$ $0,200)$. Sementara pada kelas konvensional dari hasil postes diperoleh nilai tertinggi 88 dan nilai terendah 50 dengan nilai rata-rata dan standar deviasi 65,90 $\pm 8,11$ serta memiliki sebaran data berdistribusi normal $(\mathrm{Z}=0,111 ; \mathrm{P}=0,200)$.

Berdasarkan hasil uji normalitas data, maka secara keseluruhan data berdistribusi normal dengan nilai signifikan $>0,05$. Hasil homogenitas data pretes keterampilan proses sains dinyatakan homogeny $(\mathrm{P}=$ $0,923>0,05)$ dan hasil homogenitas data postes keterampilan proses sains dinyatakan homogeny $(\mathrm{P}=0,272>0,05)$. Hasil Analysis of Covariance (Anacova) dengan bantuan SPSS 21.00 menunjukkan bahwa model pembelajaran berpengaruh signifikan terhadap keterampilan proses sains siswa $(\mathrm{F}$ $=50,953 ; \mathrm{P}=0,000 ;$ Lampiran 14). Selanjutnya uji Tukey menunjukkan bahwa terdapat pengaruh yang signifikan keterampilan proses sains siswa yang dibelajarkan dengan pembelajaran berbasis masalah dengan konvensional $(\mathrm{P}=0,00)$. Terdapat pengaruh yang signifikan keterampilan proses sains siswa yang dibelajarkan dengan model penemuan terbimbing dengan model pembelajaran berbasis masalah $(\mathrm{P}=0,00)$. Terdapat pengaruh yang signifikan keterampilan proses sains siswa yang dibelajarkan dengan model penemuan terbimbing dengan konvensional $(\mathrm{P}=0,00)$.

Hasil penelitian menunjukkan bahwa keterampilan proses sains siswa yang diajarkan dengan pembelajaran berbasis masalah menghasilkan nilai rata-rata 84,5 \pm 5,3 signifikan lebih tinggi dibandingkan keterampilan proses sains siswa yang dibelajarkan dengan model penemuan terbimbing $75,30 \pm 7,7$ dan yang dibelajarkan dengan dengan model pembelajaran konvensional $65,90 \pm 8,1$ (Gambar 1).

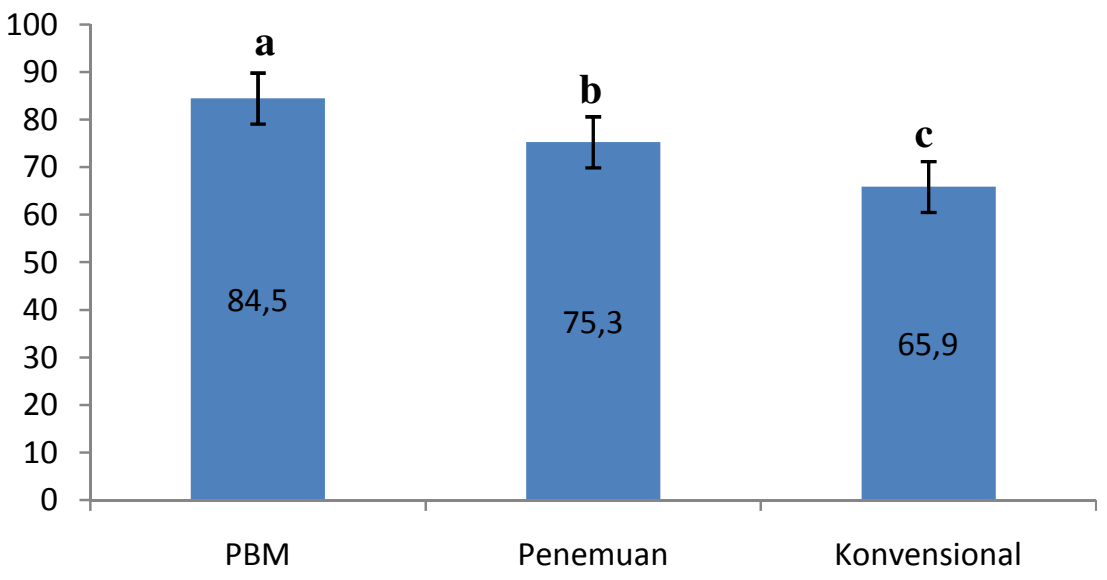

Gambar 1. Pengaruh Model Pembelajaran Berbasis Masalah, Penemuan Terbimbing dan Konvensional Terhadaap Keterampilan Proses Sains Siswa $(F=50,953 ; \mathrm{P}=0,000)$.

Hasil penelitian dan pengujian hipotesis menunjukkan bahwa adanya pengaruh yang signifikan antara siswa yang dibelajarkan dengan model pembelajaran berbasis masalah, model penemuan terbimbing pada keterampilan proses sains siswa, dimana model pembelajaran berbasis masalah dan model penemuan terbimbing lebih tinggi dibandingkan dengan pembelajaran 
konvensional. Menurut Jubjati (2011) dalam pembelajaran berbasis masalah, permasalahan dijadikan sebagai pemandu, sebagai contoh dan sebagai sarana untuk melatih siswa. Sehingga dalam proses pembelajaran berbasis masalah, siswa dapat belajar mengidentifikasi masalah, merumuskannya, berhipotesis, serta menarik kesimpulan dari masalah yang telah dipecahkan.

Rustaman (2009) menyatakan bahwa keterampilan proses sains sangat penting bagi setiap siswa sebagai bekal untuk menggunakan metode ilmiah dalam mengembangkan sains dan diharapkan dapat mengembangkan pengetahuan yang dimiliki serta mendapatkan pengetahuan baru. Udo (2010) mengemukakan bahwa dalam model penemuan terbimbing guru mengarahkan dan membantu peserta didik agar dapat menggunakan ide, konsep dan keterampilan yang sudah mereka pelajari sebelumnya untuk menemukan pengetahuan baru. Peserta didik didorong untuk berpikir dan menganalisis sendiri sehingga dapat menemukan prinsip umum berdasarkan data yang disediakan oleh guru.

Pengaruh pembelajaran berbasis masalah terhadap keterampilan proses sains terlihat dari kegiatan siswa selama pembelajaran berlangsung, dimana kegiatan pembelajaran dituntut untuk dapat memecahkan permasalahan melalui serangkaian prosedur yang harus dilakukan sehingga mereka dapat menyelesaikan permasalahan yang diberikan melalui kerja sama secara berkelompok. Hal ini sejalan dengan pendapat Sanjaya (2006) bahwa dalam pembelajaran berbasis masalah terdapat rangkaian aktifitas pembelajaran yang menekankan pada proses penyelesaian masalah yang dihadapi secara ilmiah. Menurut Akcay (2009) melalui pembelajarn berbasis masalah peserta didik lebih aktif dalam belajar, sebab mereka lebih mempunyai wewenang dan tanggung jawab untuk memecahkan dan menyelesaikan masalah. Guru bertidak sebagai fasilitator, sementara tanggung jawab berada pada peserta didik seperti tanggung jawab mengatur diri sendiri pada saat proses pembelajaran berlangsung (Savery, 2006).

Dalam pembelajaran konvensional, pembelajaran didominasi oleh guru. Materi pembelajaran disampaikan melalui metode ceramah dan buku sehingga kemampuan siswa untuk melakukan sesuatu sangat rendah dan menyebabkan keterampilan proses sainsnya tidak terbentuk. Pada saat proses pembelajaran berlangsung siswa lebih banyak mendengarkan penjelasan dari guru dan mencatat sehingga pembelajaran menjadi lebih pasif. Hal ini mengindikasikan bahwa keterampilan proses sains siswa menjadi tidak terasah.

Dengan demikian $\mathrm{H}_{\mathrm{a}}$ diterima dan $\mathrm{H}_{\mathrm{o}}$ ditolak, sehingga dapat disimpulkan bahwa terdapat pengaruh yang signifikan antara model pembelajaran berbasis masalah, penemuan terbimbing dan konvensional terhadap keterampilan proses sains siswa.

\section{SIMPULAN}

Berdasarkan hasil penelitian dan pembahasan, dapat disimpulkan bahwa:. Terdapat pengaruh yang signifikan model pembelajaran berbasis masalah, penemuan terbimbing dan konvensional terhadap keterampilan proses sains siswa SMA Negeri 1 Langsa pada materi sistem pencernaan.

\section{DAFTAR PUSTAKA}

Akcay, Behiye. 2009. Problem Based Learning in Science Education. Journal of Turkish Science Education 6 (1): 26-36..

Ango, L, M. 2002. Mastery of Science Process Skills and Their Effective Use in the Teaching of Science : An Edulogy of science Education in the Nigerian Context, International Journal of Educology. Nigeria : University of Jos 16 (1) : 1-17.

Herman. 2007. Penggunaan Pembelajaran Berbasis Masalah dalam Meningkatkan Kemampuan Berpikir Kritis Siswa Pada Pembelajaran IPS di MI Darussadah Pandeglang. Jurnal Penelitian Pendidikan 11 (2).

Jubjati. 2011. Pengaruh Pembelajaran berbasis masalah terhadap Hasil belajar Biologi dan Kemampuan Berpikir Kritis SMA Negeri 1 Batang Kuis. Tesis. Medan : Pascasarjana Unimed. 
Rustaman. 2009. Keterampilan Proses Sains. Bogor: Ghalia Indonesia.

Sanjaya, W. 2006 Strategi Pembelajaran Berorientasi Stardard Proses Pendidikan. Jakarta : Kencana Prenada Media Group.

Savery, R.J 2006. Overview of Problem basedlearning: Definition and Distinction. The interdisciplinary Journal of Problem Based Learning, 1 (1); $9-20$

Udo, M. 2010. Effect of Guided-Discovery, Student Centred Demonstration and the Expository Instructional Strategies on Studen's Performance in Chemistry. An International Multi-Diciplinary Journal, 4 (1): 1-10. 